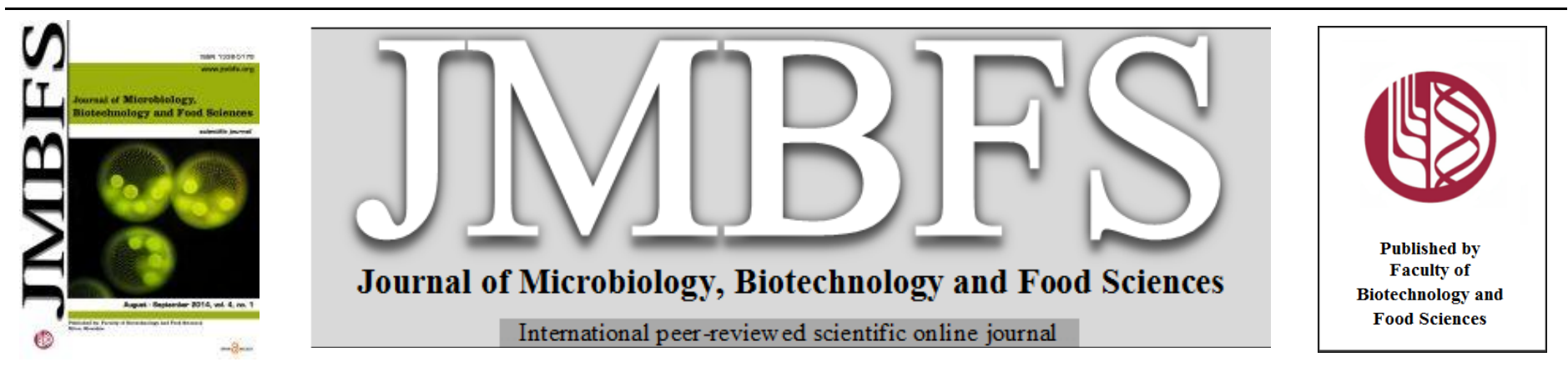

\title{
METHODS FOR DETERMINATION REACTIVE LYSINE IN HEAT-TREATED FOODS AND FEEDS
}

\author{
Matej Brestenský*, Soňa Nitrayová, Jaroslav Heger, Peter Patrášs, Ján Rafay, Alexander Sirotkin
}

Address(es): Ing. Matej Brestenský, PhD.

National Agricultural and Food Center, Research Institute of Animal Production Nitra, Institute of Nutrition, Hlohovecká 2, 95141 Lužianky, Slovakia, +4216546 182.

*Corresponding author: m_brestensky@vuzv.sk

doi: 10.15414/jmbfs.2014.4.1.13-15

\section{ARTICLE INFO}

Received 19. 5. 2014

Revised 9. 6. 2014

Accepted 10. 6. 2014

Published 1. 8. 2014

Review

open $\odot$ access

\begin{abstract}
Lysine is an essential amino acid, which is limited in foods of plant origin, especially in cereals. The heat-treatment of products containing proteins and reducing sugars results in formation of Maillard reactions during which the cross-linkages among epsilon amino groups $\left(\varepsilon-\mathrm{NH}_{2}\right)$ and reducing sugars are created. Thus the protein-carbohydrate complex is formed. This complex contains an unreactive (unavailable) lysine, which is bound to reducing sugars and is not available in body. Hereby, the nutritive value of feeds and foods decreases. When a standard analytical method for analyses of amino acids is used, in products containing protein-carbohydrate complexes, it is not possible to analyze the content of reactive (available) and unreactive (unavailable) lysine, but only the content of total lysine. Therefore, when the standard amino acid analysis is used, the content of lysine in heat-treated feeds and foods is overestimated. In order to avoid this, some methods for determination of reactive lysine were developed. Among the best known, the homoarginine and furosine methods are included. Using these methods, in evaluation of nutritive value of feeds and foods, is of great importance because they allow to determine the extent of proteins, which were damaged during the heat treatment and thus we obtain information on objective nutritional protein quality of the product.
\end{abstract}

Keywords: Feed, food, Maillard reaction, protein, reactive lysine

\section{INTRODUCTION}

The knowledge about the nutrient composition of foods and feeds is important, because based on this information we are able to find whether the full-value products for nutrition are used and whether a required content of nutrients is provided for organism. The amino acids are the basic organism building units. The foods of plant origin, general cereals, are limited in some essential amino acids, especially lysine. It is essential, both for humans and for animals. During the heat-treatment, in the raw materials and foods which contain proteins and reducing sugars, the functional (Singh, 1991) and nutritional (Friedman, 1999a; $1999 b ; 1999 c)$ properties of final products are changed as a result of changes in the structure of proteins. The attractive and low attractive odors and colors are formed and the nutritive value of products is reduced (Ajandouz et al., 2008). When the high temperatures are used, during the heat-treatment of raw materials, Maillard reactions are formed (Borrelli et al., 2003). It is chain complex of chemical reactions in which proteins, amino acids and reducing sugars are involved. The products of these reactions are responsible for the brown color and changes in organoleptic properties of feeds. Moreover, the nutritive value in the heat-treated feeds is decreased mainly as a result of decline the available lysine content (Bjorck et al., 1984). During the Maillard reaction the crosslinking among $\varepsilon$ - amino groups and reducing sugars are formed to give the unreactive (regenerated) lysine which is not digestible in the body (Fastinger and Mahan, 2006). When the content of lysine is analyzed using a standard amino acid analysis the overestimation of lysine occurs, because in this way the content of total lysine, both reactive and unreactive, is determined.

\section{Chemical changes in heat treated foods}

Besides the changes in organoleptic properties, during the heat treatment, in raw materials either plant or animal origin containing proteins and reducing sugars (glucose, lactose), a decline in nutritive value occurs as a result of formation undigestible protein-carbohydrate complexes (Bjorck et al., 1984). Irrespective of conditions which are used during the processing not all the amino acids are involved in formation of these linkages. A presence of $\varepsilon$ - amino group in lysine is responsible for a low availability of proteins because this amino group is interactive with other compounds in feeds and thus makes them unavailable. During these interactions following reactions are formed: 1) reaction of $\varepsilon-\mathrm{NH}_{2}$ group of lysine with carbonyl groups of sugars, are further transformed to
Maillard browning products (Adrian, 1974; Bjarnason and Carpenter, 1970), 2) formation of unnatural amide (isopeptide) cross-link products between $\varepsilon-\mathrm{NH}_{2}$ groups of lysine and carboxyl and amide groups of aspartic and glutamic acid or asparagine and glutamine residues (Bjarnason and Carpenter, 1970; Hurrell and Carpenter, 1977; Waibel and Carpenter, 1972), 3) formation of crosslinked amino acids such as lysinoalanine (Friedman, 1978; Sternberg et al., 1975), 4) interaction of $\varepsilon-\mathrm{NH}_{2}$ with tannins and quinones (Bjarnason and Carpenter, 1970; Dale et al., 1980; Muindi and Thomke, 1981), 5) in vivo and in vitro methylation of $\varepsilon-\mathrm{NH}_{2}$ groups to form mono-, di-, and trimethyl lysine side chains (Friedman and Gumbmann, 1981; 1979) and 6) steric blocking by adjacent disulfide bridges (Matheso, 1968).

\section{Undigestible lysine-sugar complex - unreactive lysine}

The best known reactions between lysine and reducing sugars are the Maillard reactions during which protein-saccharides complexes, not available in organism, are formed (Figure 1). During this reaction, $\varepsilon$-amino group of lysine binds to molecules of reducing sugars and thus the ileal digestibility and availability of lysine is decreased (Stein et al., 2006). Only lysine which is not linked to the reducing sugars (reactive lysine) is available in organism, while lysine linked to sugars is unavailable (Finot and Magnenat, 1981). 

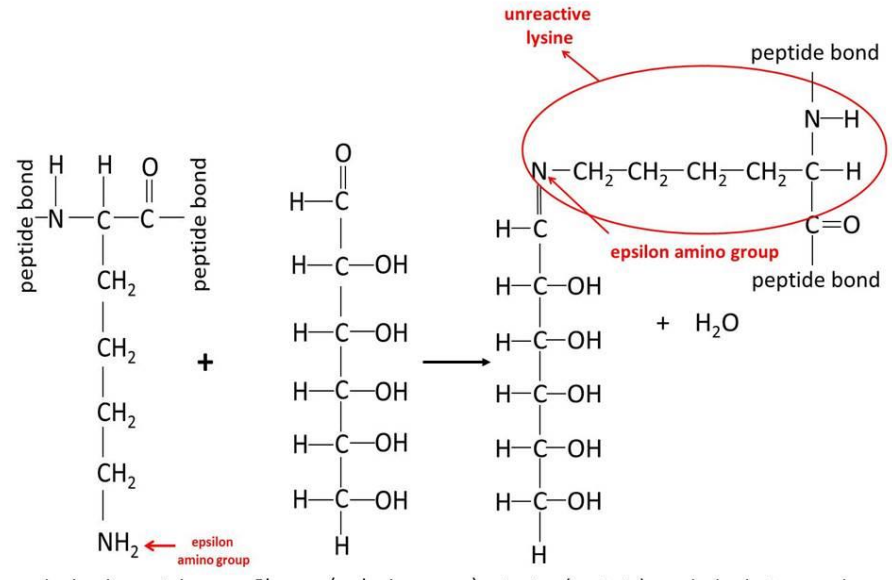

Lysine in protein Glucose (reducing sugar) Lysine (protein)- carbohydrate complex

Figure 1 Formation of protein-carbohydrates complex during the Maillard reaction

New formed lysine-sugar complex, which is resistant to enzymatic digestion in the small intestine, is cleaved during the acid hydrolysis which is one of the steps when amino acids are analyzed (Finot and Magnenat, 1981). During this step the amadori products are hydrolyzed to three amino acids: regenerated unreactive lysine, furosine and pyridosine (Finot et al., 1968), whereas reactive lysine remains as lysine. Amadori products are the intermediate formed in the formation of advanced glycation end products. These constituents are one of the factors which are responsible either for development or for deterioration of degenerative diseases such as diabetes or arteriosclerosis. During the glycation, the linkages among molecules of protein and sugars are formed resulting in damage and dysfunctional structure of proteins. Hereby the biological structure of protein is changed and biological value is reduced. Regenerated lysine, which is formed during the decomposition of amadori products, is structurally identical to the reactive lysine (Finot $\boldsymbol{e t}$ al., 1968). Lysine that appears in chromatogram, when standard amino acid analysis is used, is composed of reactive and unreactive lysine. Therefore it is not possible to distinguish between reactive and unreactive lysine. This leads to the overestimation of lysine concentration in heattreated proteins. Therefore it is necessary to find, especially in heat-treated products containing proteins and reducing sugars, the content of available lysine. For this purpose some methods for analysis of chemically and nutritionally available lysine were developed (Bodwell, 1976; Concon, 1975; Ostrowski, 1978). Among the best known, homoarginine and furosine methods belong.

\section{Furosine method}

Using furosine method the content of reactive lysine is analyzed based on the furosine concentration in heat-treated products. Furosine is amino acid which arises after acid hydrolysis of Amadori products, which are formed within the Maillard reaction by interacting $\varepsilon$ - amino groups of lysine with glucose, lactose or maltose (Nursten, 1981), during acid hydrolysis of amino acid analysis (Finot et al., 1968).

Thus furosine is considered as useful indicator of the degree of damage proteins during the Maillard reactions in many plant foods such as soy, barley, malt (Molnar-Perl et al., 1986), potato, rice (Resmini and Pellegrino, 1991), marmalades and fruit foods for newborns (Rada-Mendoza et al., 2004). The amadori products represent $32 \%$ of furosine, $40 \%$ of regenerated lysine, $28 \%$ of pyridosine (Bujard and Finot, 1978). Since the proportion of these products is constant, concentration of regenerated lysine is calculated after analysis of furosine concentration. To determine the peak of furosine in chromatogram at $570 \mathrm{~nm}, \varepsilon-\mathrm{N}-2$-furoymethyl-lysine is used (Pahm et al., 2008).

The content of Amadori products (AP) is calculated as follows: $\mathrm{AP}(\%)=$ furosine $(\%) /(32 / 100)$

Regenerated lysine which represents $40 \%$ of Amadori products is calculated: Regenerated lysine $(\%)=$ amadori product $(\%) \times(40 / 100)$

The peak of lysine which is appeared in chromatogram is identical with content of total lysine - reactive and regenerated (unreactive). The amount of regenerated lysine, calculated based on concentration of furosine, is subtracted from the total amount of lysine and thus reactive lysine is calculated:

Reactive Lys $(\%)=$ total Lys - regenerated Lys

\section{Homoarginine method}

The homoarginine method, during which a conversion of reactive lysine to homoarginine occurs, is possible to use for determination of reactive lysine (Kimmel, 1967). Within the guanidination reaction, lysine which is not linked to sugars is converted to the homoarginine before the sample is subjected to acid hydrolysis of protein (Kimmel, 1967). When homoarginine method is used the content of reactive lysine is determined based on the analyzed amount of homoarginine which is formed during the guanidination reaction. The $\mathrm{O}$ methylisourea reacts in an alkaline medium with $\varepsilon$-amino group to form a homoarginine (Figure 2).

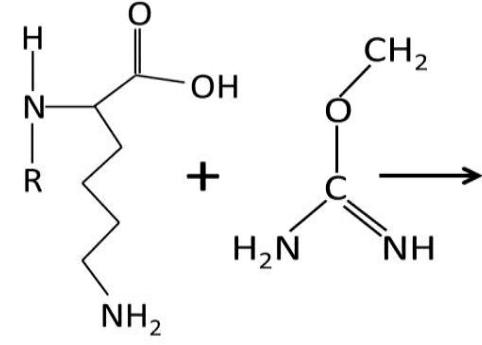

C-terminal lysine

O-Methylisourea

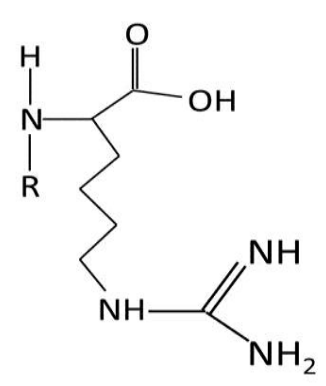

Homoarginine
Figure 2 Guanidination reaction

Homoarginine is stable in acid medium, so its' content in protein determined by conventional amino acid analysis after acid hydrolysis gives a reactive (available) lysine. During the analyses of amino acids in chromatogram a separation of reactive and unreactive lysine occurs, because reactive lysine appears as homoarginine while regenerated lysine appears as lysine. The amount of homoarginine is converted to lysine on a molar basis and the content of lysine is calculated.

Homoarginine is transformed to Lys on a molar basis using the following equation:

Reactive Lys (\%) = (homoarginine (\%) / MW homoarginine) x MW Lys, where MW homoargininge, MW Lys is molecular weight of homoarginine and lysine

The efficiency of the conversion of Lys to homoarginine is calculated using the following equation:

Lys conversion rate $(\%)=100 \times[\mathrm{mmol}$ of homoarginine $/(\mathrm{mmol}$ homoarginine + mmol lysine)]

The amount of Lys recovered after guanidination is quantified using the following equation:

Lys recovery $(\%)=100 \mathrm{x}$ (reactive Lys+ unreactive Lys) / total Lys in unguanidinated sample

The use of this technique is important in terms of nutritional quality evaluation of feeds and foods. Torbatinejad et al. (2005) found, in selected cereals, the differences in content of total and reactive lysine when this method was used. The content of total lysine was higher than reactive. The difference between reactive and total lysine ranged from $20-54 \%$. The large differences between total and reactive lysine suggest a considerable decrease of available lysine in the breakfast cereals that have been tested. Some works, reported $10 \%$ destruction and 20\% inactivation of lysine in breakfast cereals (Erbersdobler and Hupe, 1991). Also Ruthefurd $\boldsymbol{e t}$ al. (2006) reported that conventional analysis of digestible total lysine content significantly overestimated available lysine in breakfast cereals, on average $37 \%$.

\section{CONCLUSION}

During the heat-treatment of products due to cross-linking between lysine and reducing sugars the damage of proteins occurs. Protein-sugar complexes are unavailable in an organism and therefore the nutritional quality of final products is reduced. When the standard amino acid analysis is used, in heat treated foods and feeds, it is not possible to determine the content of available and unavailable lysine and therefore the content of lysine is overestimated. To avoid this, it is necessary to use methods which provide the reactive lysine content. Among the most suitable methods homoarginine and furosine method belong.

Acknowledgments: This article was written during realization of the project "ZDRAVIE no. 26220220176" supported by the Operational Programme 
Research and Development funded from the European Regional Development Fund

\section{REFERENCES}

ADRIAN, J. 1974. Nutritional and physiological consequences of the Maillard reaction. World Review of Nutrition and Dietetic, 19, 71-122.

AJANDOUZ H., DESSEAUX V., TAZI S., PUIGSERVER A. 2008. Effects of temperature and $\mathrm{pH}$ on the kinetics of caramelisation, protein cross-linking and Maillard reactions in aqueous model systems. Food Chemistry, 107(3), 12441252. http://dx.doi.org/10.1016/j.foodchem.2007.09.062

BJARNASON, J., CARPENTER, K. J. 1970. Mechanism of heat damage to proteins. I. Chemical change in pure proteins. British Journal of Nutrition, 24(1), 313-329. http://dx.doi.org/10.1079/bjn19700031

BJORCK, I., ASP, N. G., BIRKHED, D., DAHLQVIST, A. 1984. Protein nutritional value of extrusion-cooked wheat flours. Food Chemistry, 15(3), 203 214. http://dx.doi.org/10.1016/0308-8146(84)90004-9

BODWELL, C. E. 1976. Status of chemical methods to determine biologically available lysine in wheat proteins. Proc. 9th National Conference on Wheat Utilization, USDA, Seattle, p. 181-93.

BORRELLI, R. C., MENNELLA, C., BARBA, F., RUSSO, M., RUSSO, G. L., KROME, K. 2003. Characterization of coloured compounds obtained by enzymatic extraction of bakery products. Food and Chemical Toxicology, 41(10), 1367-1374. http://dx.doi.org/10.1016/s0278-6915(03)00140-6

BUJARD, E., FINOT, P. A. 1978. Mesure de la disponibilite' et du blocage de la lysine dans les laits industriels. Annales De La Nutrition Et De L Alimentation, 32, 291-305.

CONCON, J. M. 1975. Chemical estimation of critical amino acids in cereal grains and other products. Friedman, M. et al. Protein Nutritional Quality of Foods and Feeds, Part 1. New York, NY: Amazon, p. 311-379. ISBN: 0-82476278-0.

DALE, N. M., WYATT, R. D., FULLER, H. L. 1980. Additive toxicity of aflatoxin and dietary tannins in broiler chicks. Poultry Science, vol. 59, no. 11, p 2417-2420. http://dx.doi.org/10.3382/ps.0592417

ERBERSDOBLER, H. F., HUPE, A. 1991. Determination of lysine damage and calculation of lysine bioavailability in several processed foods. Journal of Nutritional Sciences, 30(1), 46-49.

FASTINGER, N. D., MAHAN, D. C. 2006. Determination of the ileal amino acid and energy digestibilities of corn distillers dried grains with solubles using grower-finisher pigs. Journal of Animal Science, 84(7), 1722-1728. http://dx.doi.org/10.2527/jas.2005-308

FINOT, P. A., MAGNENAT, E. 1981. Metabolic transit of early and advanced Maillard products. Progress in Food and Nutrition Science, 5, 193-207.

FINOT, P. A., BRICOUT, J., VIANI, R., MAURON, J. 1968. Identification of a new lysine derivative obtained from acid hydrolysis of heated milk. Experientia, 24, 1097-1099. http://dx.doi.org/10.1007/bf02147778

FRIEDMAN, M., GUMBMANN, M. R. 1979. Biological availability of epsilonN-methyl-L-lysine, 1-N-methyl-L-histidine, and 3-N-methyl-L-histidine in mice Nutrition Reports International, 79, 437- 443.

FRIEDMAN, M., GUMBMANN, M. R. 1981. Bioavailability of some lysine derivatives in mice. Journal of Nutrition, 111(8), 1362-1369.

FRIEDMAN, M. 1999a. Chemistry, biochemistry, nutrition, and microbiology of lysinoalanine, lanthionine, and histidinoalanine in food and other proteins. Journal of Agricultural and Food Chemistry, 47(4), 1295-1319. http://dx.doi.org/10.1021/jf981000+

FRIEDMAN, M. 1999b. Chemistry, nutrition, and microbiology of d-amino acids. Journal of agricultural and food chemistry, 47(9), 3457-3479. http://dx.doi.org/10.1021/jf990080u

FRIEDMAN, M. 1999c. Lysinoalanine in food and in antimicrobial proteins Advances in Experimental Medicine and Biology, Jackson, L.S. et al. Impact of Processing on Food Safety. San Francisco, CA: Springer US, vol. 459, p. 145 159. ISBN: 978-1-4613-7201-1. http://dx.doi.org/10.1007/978-1-4615-4853910

HURRELL, R. F., CARPENTER, K. J. 1977. Nutritional significance of crosslink formation during food processing. Advances in Experimental Medicine and Biology, 86, 225-238. http://dx.doi.org/10.1007/978-1-4757-9113-6 16

KIMMEL, J. R. 1967. Guanidination of proteins. Methods in Enzymology, 11, 584-589. http://dx.doi.org/10.1016/s0076-6879(67)11072-0

MOLNAR-PERL, I., PINTER-SZAKACS, M., WITTMANN, R., REUTTER, M., EICHNER, K. 1986. Optimum yield of pyridosine and furosine originating from Maillard reactions monitored by ion-exchange chromatography. Journal of Chromatography, 361, 311-320. http://dx.doi.org/10.1016/s0021 9673(01)86920-X

MUINDI, P. J., THOMKE, S. 1981. The nutritive value for rats of high- and lowtannin sorghums treated with Magadi soda. Journal of the Science of Food and Agriculture, 32(2), 139-145. http://dx.doi.org/10.1002/jsfa.2740320208

NURSTEN, H. E. 1981. Recent developments in studies of the Maillard reaction. Food Chemistry, 6(3), 263-277. http://dx.doi.org/10.1016/0308-8146(81)90014-
OSTROWSKI, H. T. 1978. Analysis for availability of amino acid supplements in foods and feeds: biochemical and nutritional implications. Friedman, M. et al Nutritional Improvement of Food and Feed Proteins. New York, NY: Plenum Press, p. 497-548, ISBN-13: 9780306400261.

PAHM, A.A, PEDERSEN, C., STEIN, H.H. 2008. Application of the Reactive Lysine Procedure To Estimate Lysine Digestibility in Distillers Dried Grains with Solubles Fed to Growing Pigs. Journal of Agriculture and Food Chemistry, 56(20), 9441-9446. http://dx.doi.org/10.1021/jf801618g

RADA-MENDOZA, M., SANZ, M. L., OLANO, A., VILLAMIEL, M. 2004 Formation of hydroxymethylfurfural and furosine during the storage of jams and fruit-based infant foods. Food Chemistry, 85(4), 605-609. http://dx.doi.org/10.1016/i.foodchem.2003.07.002

RESMINI, P., PELLEGRINO, L. 1991. Analysis of food heat damage by direct HPLC of furosine. International Chromatography Laboratory, 6, 7-11.

RUTHERFURD, S. M., TORBATINEJAD, N. M., MOUGHAN, P. J. 2006. Available (Ileal Digestible Reactive) Lysine in Selected Cereal-Based Food Products. Journal of Agricultural and Food Chemistry, 54(2), 9453-9457. http://dx.doi.org/10.1021/jf0612301

SINGH, H. 1991. Modification of food proteins by covalent crosslinking. Trends in Food Science and Technology, 2, 196-200. http://dx.doi.org/10.1016/0924. 2244(91)90683-a

STEIN, H. H., GIBSON, M. L., PEDERSEN, C., BOERSMA, M. G. 2006 Amino acid and energy digestibility in ten samples of distillers dried grain with solubles fed to growing pigs. Journal of Animal Science, 84(4), 853- 860.

TORBATINEJAD, N. M., RUTHERFURD, S. M., MOUGHAN, P. J. 2005. Total and reactive lysine contents in selected cereal-based food products. Journa of Agricultural and Food Chemistry, 53(11), 4454-4458 http://dx.doi.org/10.1021/jf050071n

WAIBEL, P. E., CARPENTER, K. J. 1972. Mechanism of heat damage in proteins. 3. Studies with e-(y-L-glutamyl)-L-lysine. British Journal of Nutrition, 27(3), 509-515. http://dx.doi.org/10.1079/bjn19720120 